





\section{A Review of \\ Water Resources of the \\ Umiat Area, Northern Alaska}

By John R. Williams

GEOLOGICAL SURVEY CIRCULAR 636




United States Department of the Interior

WALTER J. HICKEL, Secretary

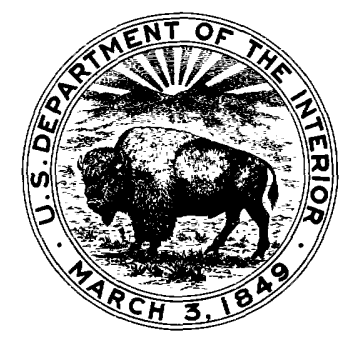

Geological Survey

William T. Pecora, Director

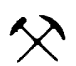

Free on application to the U.S. Geological Survey, Washington, D.C. 20242 


\section{CONTENTS}

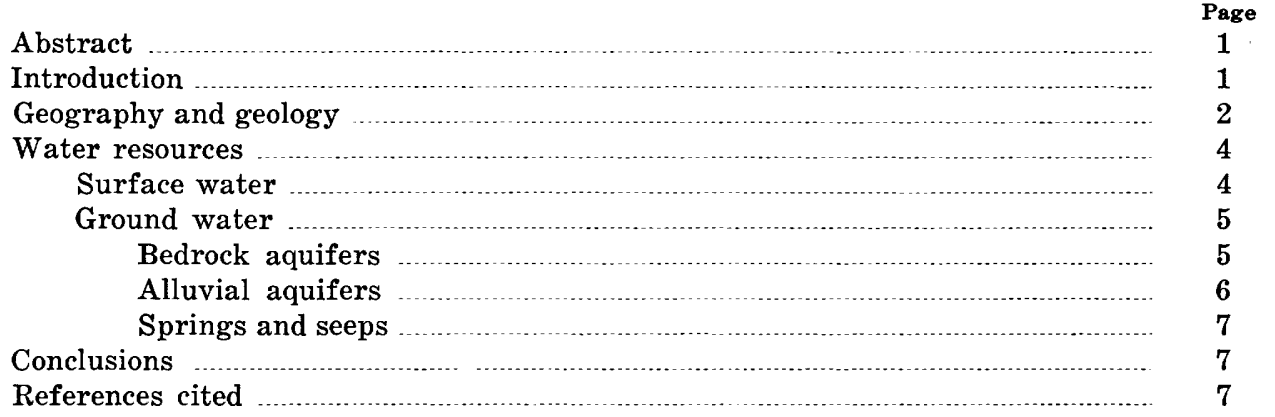

\section{ILLUSTRATIONS}

Figure 1. Map of Umiat area showing location of exploratory test wells in foothills and in Colville River valley.

2. Well location map, Colville River valley at Umiat.

\section{TABLES}

TABLE 1. Subsurface data in the Umiat area

2. Analysis of Colville River water near Umiat 


\title{
A REVIEW OF WATER RESOURCES OF THE UMIAT AREA, NORTHERN ALASKA
}

\author{
By JOHN R. WILLIAMS
}

\begin{abstract}
Surface-water supplies from the Colville River, small tributary creeks, and lakes are abundant in summer but limited in winter by low or zero flow in streams and thick ice cover on lakes.

Fresh ground water occurs in unfrozen zones in alluvium and in the upper part of bedrock beneath the Colville River and beneath lakes that do not freeze to the bottom in winter. These unfrozen zones, forming depressions in the upper surface of permafrost, are maintained by flow of heat from bodies of surface water into subjacent alluvium and bedrock.

Brackish or saline ground water occurs in bedrock beneath as much as 1,055 feet of permafrost in the Arctic foothills and beneath 750 to 800 feet of permafrost beneath low terraces of the Colville River valley. The foothill area is unfavorable for developing supplies of potable ground water because of the great depth to water, predominance of brackish or saline water, and low potential yield of the bedrock. In the Colville River valley, shallow unfrozen alluvium beneath the river and deep lakes will yield abundant year-round supplies of ground water, but the bedrock below permafrost yields less than $10 \mathrm{gpm}$ (gallons per minute) of saline or brackish water.
\end{abstract}

\section{INTRODUCTION}

The Umiat area is in the Arctic (northern) foothills of the Brooks Range at lat $69^{\circ} 22^{\prime}$ $30^{\prime \prime}$ N., long $152^{\circ} 08^{\prime} 30^{\prime \prime}$ W. (fig. 1). The settlement and adjacent airstrip lie on low terraces north of the Colville River near the mouth of Sea Bee Creek. The camp was established during exploration for petroleum in Naval Petroleum Reserve No. 4. Development of the Prudhoe Bay field to the northeast and exploration for oil and gas in leases bordering the Reserve east of the Colville River may lead to growth of the settlement and may increase demand for a dependable year-round supply of potable water. The existing system obtains water from surface sources and melted snow and ice.
Locating and developing supplies of water to meet future needs at Umiat and at other settlements in northern Alaska is made difficult by the presence of saline or brackish water in bedrock, widespread occurrence of permafrost that extends to depths of 500 to 1,330 feet, intermittent winter flow of rivers, and deep freezing of surface-water bodies. Nevertheless, abundant ground water occurs in unfrozen alluvium that occupies depressions in the upper surface of permafrost beneath deep lakes and rivers. Ground water from such sources generally is warmer in winter and less likely to freeze in distribution lines than surface water and does not contain suspended sediment. Use of ground water eliminates problems of icing of surfacewater intakes by frazil or anchor ice in rivers and problems of insufficient river flow in winter. Aquifers beneath lakes have a larger storage capacity than a surface-water supply limited to water between the lake bottom and ice cover.

The purpose of this report is to describe potential sources of surface water and ground water in the Umiat area and to point out possibilities for developing year-round supplies of ground water in shallow unfrozen alluvial aquifers beneath rivers and deep lakes. The principles relating to occurrence of water in the Umiat area apply to other parts of the Colville River valley and to other large valleys of northern Alaska.

This report was prepared as part of a compilation of existing data on the occurrence of ground water in permafrost regions; it is based entirely on office studies of reports by Black (1955), Black and Barksdale (1948), Brewer (1958a), and Collins (1958). 


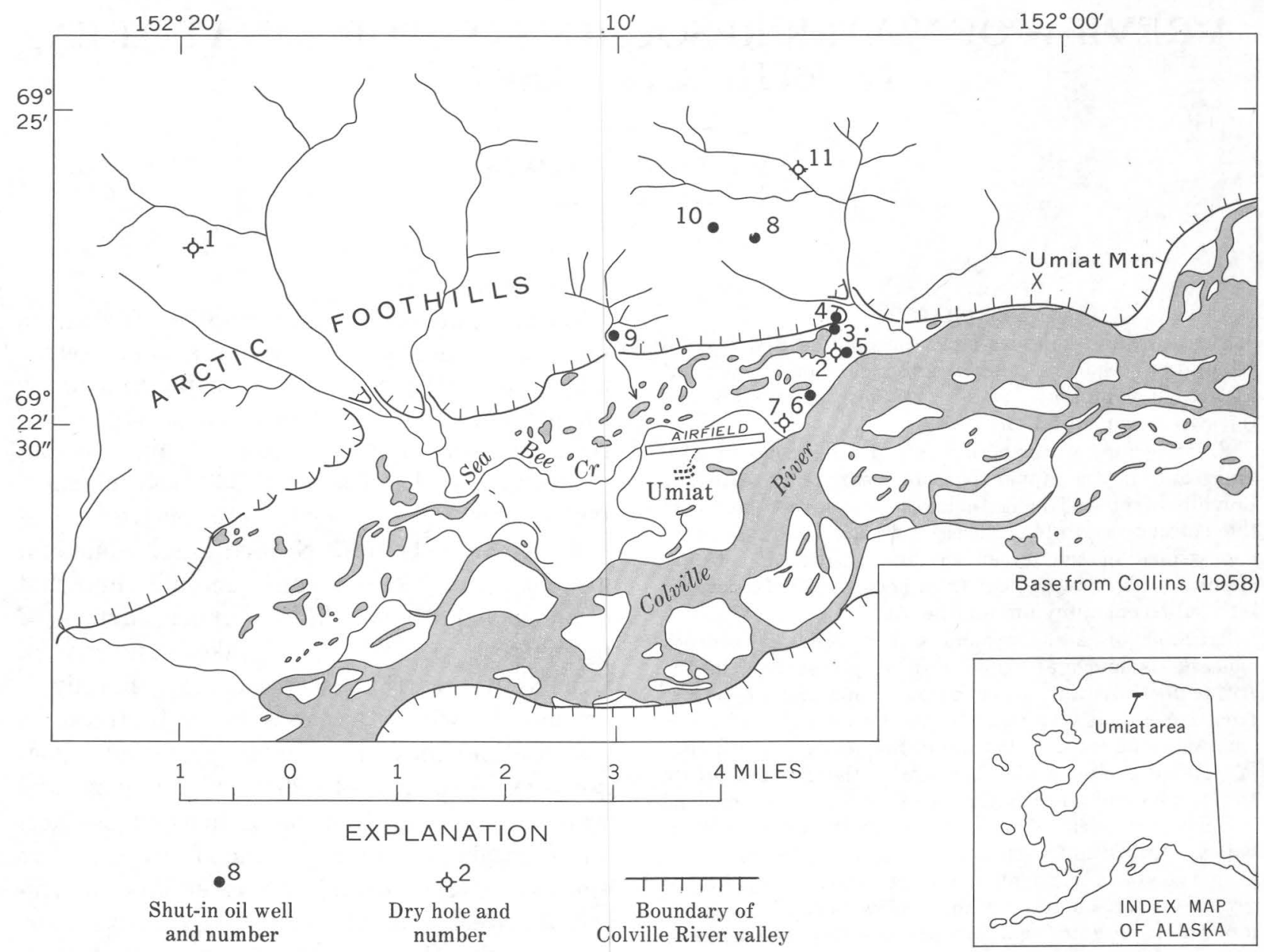

FIgure 1.-Location of exploratory test wells in foothills and Colville River valley.

\section{GEOGRAPHY AND GEOLOGY}

At Umiat the Colville River, the largest in northern Alaska, flows N. $80^{\circ}$ E. in a braided channel within a valley 2 to 4 miles wide (fig. 1). The valley, 330 to 340 feet above sea level near Umiat, consists of riverbed, bars and islands of the flood plain, and low lake-dotted terraces that separate the flood plain from the hills. The hills bordering the valley are part of the Arctic foothills of the Brooks Range. Steep bluffs border the river where it impinges against the hillsides, as at Umiat Mountain, 600 feet above the valley floor (fig. 1).

Bedrock in the vicinity of Umiat is of Cretaceous age (Collins, 1958, p. 73) and consists of clay-shale and sandstone which, in the upper part, is interbedded locally with bentonite, clay ironstone, and coal. The rocks are in broad open folds that are cut locally by faults. Northeast of
Umiat the eastward-trending Umiat anticline is cut by the river at Umiat Mountain where seeps of oil led to exploration and drilling.

Unconsolidated deposits in the Colville River valley are of Pleistocene and Holocene age (Black and Barksdale, 1948, p. 8; Collins, 1958, p. 73) and consist of interbedded alluvial gravel, sand, and silt in the flood plain and low terraces. The gravel and sand are made up of subrounded to rounded grains of yellow, white, and black chert and clear quartz. The deposits are as much as 71 feet thick (table 1).

Permafrost, as measured in wells drilled for petroleum, extends to a depth of 535 to 1,055 feet in the foothills north of the Colville River and to a depth of 750 to 800 feet beneath low terraces north of the river (figs. 1 and 2; table 1 ) (Brewer, p. 132, 142, 170, and 197, in Collins, 1958; Collins, 1958, p. 99; Reed, 1958, p. 78). 
TABLE 1.-Subsurface data in the Umiat area

\begin{tabular}{|c|c|c|c|c|c|c|}
\hline $\begin{array}{l}\text { Well in } \\
\text { figs. } \\
1 \text { and } 2\end{array}$ & $\begin{array}{l}\text { Name and type } \\
\text { of well or hole }\end{array}$ & $\begin{array}{l}\text { Total } \\
\text { depth } \\
\text { (feet) }\end{array}$ & $\begin{array}{l}\text { Thickness } \\
\text { of } \\
\text { alluvium } \\
\text { (feet) }\end{array}$ & $\begin{array}{l}\text { Depth to } \\
\text { base of } \\
\text { permafrost } \\
\text { (feet) }\end{array}$ & $\begin{array}{l}\text { Occurrence and yield of ground } \\
\text { water: results of formation } \\
\text { tests }\end{array}$ & $\begin{array}{l}\text { Sources of } \\
\text { information }\end{array}$ \\
\hline 1 & $\begin{array}{l}\text { Umiat Test Well 1, } \\
\text { dry hole. }\end{array}$ & 6,005 & $\ldots$ & 920 & $\begin{array}{l}\text { Formation test } 1,693-1,816 \mathrm{ft} \\
\text { produced } 9 \mathrm{gpm} \text { fresh water. }\end{array}$ & Collins, 1958, p. $95-99$ \\
\hline \multirow[t]{2}{*}{2} & $\begin{array}{l}\text { Umiat Test Well 2, } \\
\text { dry hole. }\end{array}$ & 6,212 & 71 & 750 & $\begin{array}{l}\text { Formation test } 103-345 \mathrm{ft} \\
\text { when hole cased to } 100 \mathrm{ft} \text {; } \\
\text { dissolved-solids cencentrations } \\
1,031 \mathrm{mg} / \mathrm{l} \text {, chloride } 173 \mathrm{mg} / \mathrm{l}\end{array}$ & $\begin{array}{l}\text { Collins, 1958, } \\
\text { p. 99-116; Reed, } \\
\text { 1958, p. } 78 .\end{array}$ \\
\hline & & & & & $\begin{array}{l}\text { Formation test after reaching } \\
\text { total depth; water level } 730 \mathrm{ft} \text {; } \\
\text { dissolved-solids concentrations } \\
3,188 \mathrm{mg} / 1 \text {; chloride } 1,176 \mathrm{mg} / 1 \text {. }\end{array}$ & \\
\hline 3 & $\begin{array}{l}\text { Umiat Test Well 3, } \\
\text { shut-in oil well. }\end{array}$ & 572 & $-\cdots-$ & $\cdots-$ & No water. & $\begin{array}{l}\text { Collins, 1958, } \\
\text { p. 116-125. }\end{array}$ \\
\hline 4 & $\begin{array}{l}\text { Umiat Test Well } 4, \\
\text { shut-in oil well. }\end{array}$ & 840 & $-\cdots$ & $\$ 97$ & Unknown. & $\begin{array}{l}\text { Brewer, p. 131-132 in } \\
\text { Collins, 1958; } \\
\text { Collins, 1958, } \\
\text { p. 125-131. }\end{array}$ \\
\hline 5 & $\begin{array}{l}\text { Umiat Test Well 5, } \\
\text { shut-in oil well. }\end{array}$ & 1,077 & 28 & 800 & $\begin{array}{l}\text { Fresh water in upper } 28 \mathrm{ft} \text { of } \\
\text { alluvium sealed off by casing; } \\
\text { salt water at probable base of } \\
\text { permafrost. }\end{array}$ & $\begin{array}{l}\text { Collins, 1958, } \\
\text { p. 132-138. }\end{array}$ \\
\hline 6 & $\begin{array}{l}\text { Umiat Test Well } 6, \\
\text { shut-in oil well. }\end{array}$ & 825 & $28+$ & 770 & $\begin{array}{l}\text { Water first noted at } 825 \mathrm{ft} \text {; } \\
\text { sample taken from tank during } \\
\text { pumping test; dissolved-solids } \\
\text { concentrations } 7,928 \mathrm{mg} / \mathrm{l} ; \\
\text { chloride } 1,400 \mathrm{mg} / \mathrm{l} .\end{array}$ & $\begin{array}{l}\text { Brewer, p. 142, in } \\
\text { Collins, 19E8; } \\
\text { Collins, 1958, } \\
\text { p. 138-142. }\end{array}$ \\
\hline 7 & $\begin{array}{l}\text { Umiat Test Well } 7 \text {, } \\
\text { dry hole. }\end{array}$ & 1,384 & $35+(?)$ & 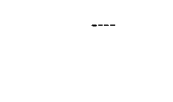 & $\begin{array}{l}\text { A bove } 485 \mathrm{ft} \text { small amount of } \\
\text { fresh water; below } 485 \mathrm{ft} \\
\text { salinity values affected by } \\
\text { brine drilling fluid. }\end{array}$ & $\begin{array}{l}\text { Colling, 1958, } \\
\text { p. } 143-148 .\end{array}$ \\
\hline 8 & $\begin{array}{l}\text { Umiat Test Well 8, } \\
\text { shut-in oil well. }\end{array}$ & 1,327 & --- & $535(?)$ &  & $\begin{array}{l}\text { Collins, } 1958, \\
\quad \text { p. } 148-155 .\end{array}$ \\
\hline 9 & $\begin{array}{l}\text { Umiat Test Well 9, } \\
\text { shut-in oil well. }\end{array}$ & 1,257 & $-\cdots$ & 1,055 & $-1-1-1-1-1-1$ & $\begin{array}{l}\text { Brewer, p. } 170-171 \text { in } \\
\text { Collins, 1958; } \\
\text { Collins, 1958, } \\
\text { p. 158-170. }\end{array}$ \\
\hline 10 & $\begin{array}{l}\text { Umiat Test Well 10, } \\
\text { shut-in oil well. }\end{array}$ & 1,573 & --- & $-\ldots$ & - & $\begin{array}{l}\text { Collins, 1958, } \\
\text { p. 171-178. }\end{array}$ \\
\hline 11 & $\begin{array}{l}\text { Umiat Test Well 11, } \\
\text { dry hole. }\end{array}$ & 3,303 & --- & $770(?)$ & $\begin{array}{l}\text { Brackish water recovered in } \\
\text { formation tests (see text p. } 5 \text { ). }\end{array}$ & $\begin{array}{l}\text { Brewer, p. } 197 \text { in } \\
\text { Collins, 1958; } \\
\text { Collins, 1958, } \\
\text { p. } 179-198 .\end{array}$ \\
\hline 12 & Seismic shot hole & 45 & 23 & $45+$ & 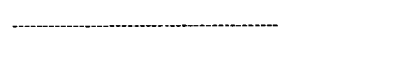 & $\begin{array}{c}\text { Black and Barksdale, } \\
1948, \text { hole 1, p. } 14 .\end{array}$ \\
\hline 13 & do & 45 & 31 & $45+$ & 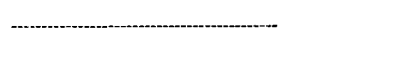 & $\begin{array}{c}\text { Black and Barksdale, } \\
1948, \text { hole } 2, \text { p. } 14 .\end{array}$ \\
\hline 14 & do & 45 & 23 & $45+$ & 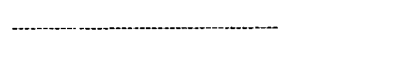 & $\begin{array}{c}\text { Black and Barksdale, } \\
1948 \text {, hole } 3, \text { p. } 14 .\end{array}$ \\
\hline 15 & do & 45 & 29 & $45+$ & - & $\begin{array}{c}\text { B̈lack and Barksdale, } \\
1948, \text { hole } 4, \text { p. } 20 .\end{array}$ \\
\hline 16 & do & 42 & 24 & $\begin{array}{l}\text { Above } 13 \mathrm{ft} \\
18-42+\mathrm{ft}\end{array}$ & $\begin{array}{l}\text { Water-bearing sand and gravel } \\
\text { between } 13 \text { and } 18 \mathrm{ft} .\end{array}$ & $\begin{array}{l}\text { Black and Barksdale, } \\
1948 \text {, hole } 5, \text { p. } 12, \\
20 \text {, and fig. } 2 .\end{array}$ \\
\hline 17 & do & 44 & 25 & $\begin{array}{l}\text { Above } 11 \mathrm{ft} \\
22-44+\mathrm{ft}\end{array}$ & $\begin{array}{l}\text { Unfrozen zone between } 11 \text { and } \\
22 \mathrm{ft} .\end{array}$ & $\begin{array}{c}\text { Black and Barksdale, } \\
1948, \text { hole } 6, \text { p. } 20 .\end{array}$ \\
\hline 18 & do. & 48 & 41 & $48+$ & 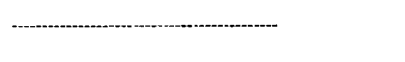 & $\begin{array}{c}\text { Black and Barksdale, } \\
1948, \text { hole } 7, \text { p. } 20 .\end{array}$ \\
\hline 19 & do & 41 & 25 & $\cdots$ & -- & \\
\hline 20 & do & 44 & 28 & -- & 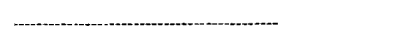 & Do. \\
\hline 21 & do & 47 & 31 & --- & -1. & Do. \\
\hline
\end{tabular}

Although no test wells or shallow borings have been drilled in the riverbed, bars, or islands of the flood plain, the upper surface of permafrost probably is deep beneath the river because of the warming effect of the river on subjacent alluvium and bedrock. Similar depressions in the upper surface of permafrost beneath lakes that do not freeze to the bottom in winter probably are not as deep nor as wide as that boneath the river.

Locating and delimiting the extent of unfrozen zones beneath rivers and lakes may b? done by test drilling, geothermal methods, or geophysical investigations. Test drilling is of limited value because distinguishing between frozen and unfrozen fine-grained bedrock is 


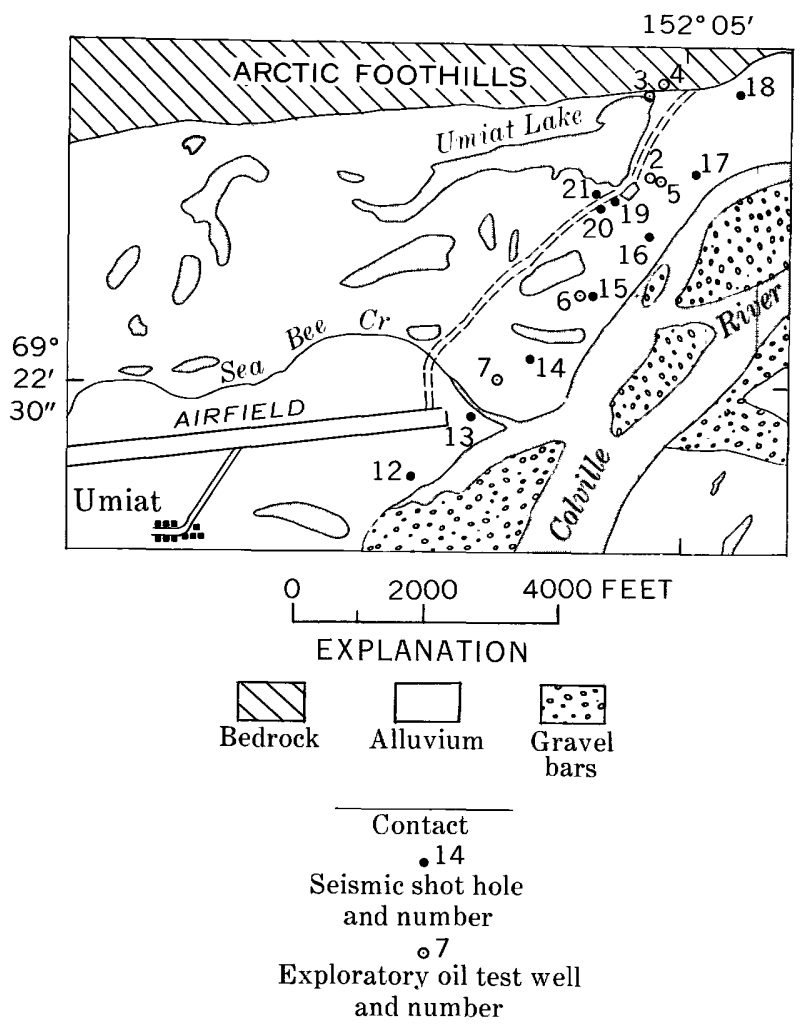

Figure 2.-Well locations in the Colville River valley at Umiat.

based on action of the drill which may be difficult to evaluate. Geothermal methods described by Lachenbruch (1957) and Brown (1963) require information on the mean annual ground surface temperature, mean annual water temperature (or mean annual temperature of the lake bottom or riverbed), regional geothermal gradient, and history of changes in size and shape of the water body. These data are not available in the Umiat area. The seismic refraction method is the most suitable geophysical method for determining the position of the upper surface of permafrost (Barnes, 1964) and could be applied at Umiat to determine the thickness of unfrozen zones beneath the river and deep lakes.

\section{WATER RESOURCES}

Surface-water resources of the Umiat area include the Colville River, its tributaries, and lakes. Ground-water resources consist of brackish or saline water in bedrock below permafrost and fresh, potable water in alluvium and shal- low bedrock above the permafrost beneath the river and deep lakes.

\section{SURFACE WATER}

Discharge of the Colville River at Umiat, measured only in 1953, ranged from zero flow on April 2 to $13,000 \mathrm{cfs}$ (cubic feet per second) on September 10 (U.S. Geological Survey, 1958, p. 208). Freezing forms 6 to 9 feet of ice on rivers and lakes by late winter, but deep pools in the river channel and the deeper lakes provide year-round sources of water. In February 1954 water temperature, measured beneath a 5-foot ice cover in a channel 17 feet deen, ranged from $0^{\circ} \mathrm{C}$ (Celsius) at the base of the ice to about $0.5^{\circ} \mathrm{C}$ at the bottom of the river (Brewer, 1958a, fig. 9). The positive bottom temperature shows that the alluvium beneath the river is above the freezing point in winter. The nearly uniform temperature suggests that the river was flowing at this time. Although the river had no flow in April 1953, perennial flow has been reported in other years (Black and Barksdale, 1948). Thick masses of frazil ice accumulate in deep pools and anchor ice probably forms along the bottom of the river; during 1953, frazil ice 12 feet deep was reported.

Quality of water of the Colville River at a discharge of 6,500 cfs is excellent, on the basis of an analysis of a single sample co'lected July 28, 1953 (table 2). No data are available to show changes in composition of the water during winter. The river carries suspended sediment during the spring runoff and at other peak flows, but at low stage the river is free of suspended sediment.

TABLE 2.-Analysis of Colville River vater near Umiat [U.S. Geological Survey, 1958, r. 239]

\begin{tabular}{|c|c|}
\hline Chemical constituents & $\underset{\text { per liter }}{\text { Milligrams }}$ \\
\hline Silica $\left(\mathrm{SiO}_{2}\right)$ & 1.9 \\
\hline Calcium (Ca) & 13 \\
\hline Magnesium ( $\mathrm{Mg}$ ) & 4.8 \\
\hline Sodium (Na) & 1.5 \\
\hline Potassium (K) & .5 \\
\hline Bicarbonate $\left(\mathrm{HCO}_{3}\right)$ & 53 \\
\hline Sulfate $\left(\mathrm{SO}_{4}\right)$ & 10 \\
\hline Chloride (Cl) & .5 \\
\hline Nitrate $\left(\mathrm{NO}_{3}\right)$ & .3 \\
\hline Dissolved solids (residue on & \\
\hline evaporation at $180^{\circ} \mathrm{C}$ ) & 59 \\
\hline Hardness as $\mathrm{CACO}_{3}$ : & \\
\hline Calcium, magnesium & 52 \\
\hline Noncarbonate & 8 \\
\hline $\begin{array}{l}\text { Specific conductance } \\
\text { pH }\end{array}$ & $\begin{array}{l}109 \\
6.8\end{array}$ \\
\hline
\end{tabular}


Sea Bee Creek, the largest of the tributaries of the Colville River in the Umiat area, drains the foothills and follows abandoned channels of the Colville as it crosses the low terraces. The creek is reported to freeze to its bed in winter (Reed, 1958, p. 60). Although creeks like Sea Bee Creek provide a source of water in summer, little or no water is available from them in winter. No determinations of flow or quality of the water have been made.

Numerous lakes occupy abandoned channels on the low terraces bordering the Colville River. The ice cover of 6 to 9 feet eliminates many of the shallower lakes and shallow sections of deep lakes as sources of water during winter. The temperature of Umiat Lake (fig. 2), one of the largest and deepest lakes in this part of the Colville Valley, was studied by Brewer (1958a) in February 1954. Water temperature ranged from $0^{\circ} \mathrm{C}$ beneath a 5 -foot ice cover to $4{ }^{\circ} \mathrm{C}$ at the bottom of the lake, 12 feet below the ice surface. In summer, water of lakes near Umiat reportedly contains a high concentration of organic compounds that make it objectionable for drinking (Black and Barksdale, 1948, p. 10). Although no analyses are available, the concentration may be increased as volume of the lake is decreased by freezing of its surface. Limited year-round supplies of poor quality water are available from lakes that do not freeze to the bottom. Shallower lakes are sources of supply only in summer.

\section{GROUND WATER}

Ground water occurs in porous, permeable beds and fractures in bedrock and in alluvial sand and gravel. The water in bedrock beneath permafrost in the northern Alaska is generally saline or brackish. Within the Colville River valley, water in unfrozen zones in the alluvium and in the upper part of bedrock beneath the river is fresh. Fresh water also occurs in unfrozen alluvium beneath lakes that do not freeze to the bottom in winter and in local unfrozen zones in terrace alluvium near the lakes and the river.

\section{BEDROCK AQUIFERS}

Bedrock aquifers consist of permeable finegrained sandstone and fractured sandstone and clay-shale of Cretaceous age. The lithology, stratigraphy, and structure of these rocks is given in greater detail in Collins (1958). Yield of bedrock aquifers in the Umiat area and elsewhere in the foothills and Arctic coastal plain is only rarely as great as $10 \mathrm{gpm}$ (gallons per minute).

In the foothill belt north of the Colville River (fig. 1) six exploratory oil wells were drilled in bedrock through 535 to 1,055 feet of permafrost. Water was reported in only two of these wells. In test well 11 brackish water was obtained from formation tests at depths between 2,094 to 2,850 feet, as follows:

\begin{tabular}{|c|c|c|}
\hline Depth & $\begin{array}{c}\text { Dissolved } \\
\text { solids } \\
(m g / l)\end{array}$ & Chloride \\
\hline $2,094.5-2,145$ & $\ldots 4,290$ & \\
\hline $2,375 \quad-2,411$ & 6,900 & 1,600 \\
\hline $\begin{array}{ll}2,447 & -2,461 \\
2,814 & -2,830\end{array}$ & 6,434 & 865 \\
\hline $2,832-2,850$ & 6,543 & $1, \dddot{950}$ \\
\hline
\end{tabular}

In well 1 water entered at a rate of $9 \mathrm{gpm}$ in a formation test of rocks between 1,693 and 1,816 feet in depth (table 1) (Collins, 1958). On the basis of drilling and formation tests at Umiat and elsewhere, bedrock of the foothills is not regarded as a significant source of water because of high salinity, low yield, and great depth to water.

Ground water in bedrock beneath the low terraces north of the Colville River is reported in four of five exploratory oil wells. The water below the base of permafrost ( 750 to 800 feet) has a higher salinity than acceptable standards for public supplies.

Fresh ground water reportedly, was obtained from the upper part of bedrock in two wells in the Colville River valley. In well 2 , about 250 feet east of Umiat Lake, water having 1,031 $\mathrm{mg} / \mathrm{l}$ (milligrams per liter) dissolved solids was obtained from a formation test of bedrock between 103 and 345 feet. The test was made after installation of 100 feet of casing, but the effectiveness of the casing in sealing off any water in the 71 feet of surficial alluvium overlying bedrock was not reported. In well 7, located about 700 feet from the Colville River and 500 feet from Sea Bee Creek (fig, 2), fresh water was reported in the upper 485 feet. but no analyis was made, nor was the depth of the water-bearing zone specified. If these reports of fresh water in bedrock in wells near bodies of surface water are correct, the unfrozen zone beneath Umiat Lake and beneath the Colville 
River may extend laterally beneath the low terraces. The depth to which fresh water was reported in well 2 suggests that the unfrozen zone beneath Umiat Lake is at least 103 feet deep and perhaps more than 345 feet. These suggested depths are reasonable when compared with the 190 -foot depth of the upper surface of permafrost beneath Imikpuk Lake, a much smaller lake near Barrow, where the mean annual ground surface temperature is comparable to that at Umiat (Brewer, $1958 \mathrm{~b})$. If fresh water reported in well 7 to a depth of about 485 feet is derived from a lateral extension of the unfrozen zone beneath Colville River, the unfrozen zone beneath the river may extend to a depth of 485 feet or even deeper, perhaps completely perforating the permafrost as postulated by Black (1955, p. 119; Black and Barksdale, 1948).

\section{ALLUVIAL AQUIFERS}

Porous and permeable sand and gravel 23 to 71 feet thick was penetrated in five exploratory oil wells and 10 seismic shot holes drilled in low terraces north of the Colville River (fig. 2). In all but three holes the alluvium is frozen from near the surface to its base. Heat flow by conduction from the river and lakes maintains year-round unfrozen zones in subjacent alluvial deposits. Three holes located near Umiat Lake and the Colville River penetrated unfrozen zones in the alluvium that are probably lateral extensions to those beneath the lake and the river.

Unfrozen alluvium beneath the Colville River is recharged directly by surface water or by underflow through the bed of the river from points upstream. The alluvium provides a greater volume of storage and potential recharge than any other source of water in the Umiat area. Athough data on yields from alluvial deposits are not available, the thickness and character of the deposits suggest that wells might yield as much as several hundred gallons per minute. During periods of low or zero river flow in winter, deep pools in the river and water stored in the unfrozen alluvium probably would provide ample recharge and storage throughout winter. A well or gallery pumping from alluvium beneath the river probably would induce infiltration of river water that contains a low proportion of dissolved solids and organic constituents. No data are available on the depth of scour or rate of bank erosion that might affect the useful life of galleries beneath the river or wells on its bank.

Unfrozen alluvium beneath lakes has a more limited source of recharge and volume of storage than that beneath the river. Winter recharge to the alluvial aquifer beneath lakes is limited to lake water beneath the ice cover. The rate at which lake water woxld replenish a pumped aquifer would depend on the thickness and permeability of organic material and silty bottom sediments that separate the lake from the underlying alluvial aquifer. Quality of ground water beneath lakes probably is similar to that of the lake, although no analyses of either lake water or ground water are available.

Three holes, all within 400 feet of either the river or a deep lake, were drilled through unfrozen zones in the alluvium that may be lateral extensions of the unfrozen zones beneath the river or lakes. Test well 5 reportedly produced fresh water in the alluvium in the upper 28 feet of the hole. Unfrozen gravel was penetrated between 13 to 18 feet in shot hole 16 and between 11 and 22 feet in shot hole 17. Gravel in hole 16 contained water and is believed to be a lateral extension of the unfrozen alluvium beneath the Colville River, only 300 feet away (Black and Barksdale, 1948). Water from such unfrozen zones may be higher in dissolved solids than that indicated by river water sampled in summer. The water level may fluctuate with the stage of the river. Drilling wells at locations on the low terrace adjacent to rivers or lakes is more convenient than drilling at an angle to intercept aquifers beneath bocies of water. However, locating productive infrozen zones in the terrace deposits near the river and lakes is more difficult than locating those beneath the river and lakes. From experience elsewhere, unfrozen zones in low terrace alluvium may be more common and larger on the slipoff side than along the former cutbanks of the river or linear oxbow lakes. Unfrozen zones may be more common along the ends of these linear lakes but within the abandoned river channels than along the sides. 
SPRINGS AND SEEPS

Springs were noted in 1946 between the airfield and Umiat camp (fig. 2). Black and Barksdale (1948, p. 10) report that the water temperature was $1.1^{\circ} \mathrm{C}$ and the source of the springs is from surface thaw and not from unfrozen layers within the alluvium. They report that several unsuccessful attempts were made to locate a supply of ground water in the alluvium near the camp. However, Reed (1958, p. 54), without commenting on the source of the water, reports that a shallow well dug near the spring provided water for the camp.

No springs or seeps beneath the river are known in the Umiat area. The chemical character of the river water, judging from a sample collected in summer, suggests that it is not fed by seepage of brackish or saline ground water from bedrock beneath permafrost. However, analysis of river water during low winter flow should be made to determine the proportion of winter flow from bank storage in the alluvium and underflow and that from saline or brackish ground water. Abnormally high chloride concentration in such analysis would suggest that saline or brackish water is discharged to the river in winter from the bedrock.

\section{CONCLUSIONS}

In the Colville River valley, water from the river, its small tributaries, and lakes is limited or unavailable in winter when streamflow ceases or is very low and the lakes are largely covered by ice. Year-round supplies of fresh ground water occur in unfrozen aquifers beneath the Colville River and lakes that do not freeze to the bottom in winter, and in local areas of the low terraces near lakes and the river. Yields from these aquifers probably are several hundred gallons per minute from alluvium but less than $10 \mathrm{gpm}$ from bedrock. Quality of water probably is best in alluvium immediately beneath the river, but dissolved solids appear to increase in concentration with depth. Brackish or saline water may be expected in bedrock below permafrost. Dissolved organic material may be present in ground water beneath lakes. Storage and recharge potential are large in alluvium beneath the river and less beneath lakes.
In the Arctic foothills north of Umiat ground water occurs in permeable beds and fractures in bedrock below permafrost. However, the great depth to water, low yield, and predominance of brackish or saline water indicate that the foothills are unfavorable for developing supplies of potable ground water.

Principles relating to the development of unfrozen zones or depressions in the upper surface of permafrost beneath rivers anc deep lakes by conductive heat flow from the water to subjacent alluvium and bedrock have been established by geothermal studies in northern Alaska (Brewer, 1958a, b; Lachenbruch, 1957; Lachenbruch and others, 1962). These principles have been applied through use of grephical solutions in the Mackenzie Valley of Canada (Brown, 1963), and can be quantitatively applied to the search for water-bearing unfrozen zones above permafrost in alluvial deposits at Umiat when the requisite basic data become available. The principles applied qualitatively to the Umiat area in this report may be $\varepsilon$ pplied elsewhere in the Colville Valley and in other valleys of the Arctic where geologic and hydrologic conditions are comparable.

\section{REFERENCES CITED}

Barnes, D. F., 1965, Geophysical methods for delineating permafrost: Internat. Conf. on Permafrcst, Lafayette, Ind., 1963, Proc., p. 349-355.

Brewer, M. C., 1958a, Some results of geothermal investigations of permafrost in northern Alaska: Am. Geophys. Union Trans., v. 39, no. 1, p. 19-26.

$1958 \mathrm{~b}$, The thermal regime of an Arctic lake: Am. Geophys. Union Trans., v. 39, no. 2, p. 278-284.

Black, R. F., 1955, Arctic Slope in Hopkins, D. M., Karlstrom, T. N. V., and others, Permafrost and ground water in Alaska: U.S. Geol. Survey Prof. Paper 264-F, p. 118-119.

Black, R. F. and Barksdale, W. L., 1948, Terrain and permafrost, Umiat area, Alaska: U.S. Geol. Survey Permafrost Program Progress Rept. 5, 23 p.; pub. by Eng. Intelligence Div., Office, Chief of Engineers, U.S. Army.

Brown, W. G., 1963, Simple graphical methods for estimating the location of permafrost under shallow lakes and rivers in Brown, R. J. E., ed., Proceedings of the 1st Canadian Conf. on Permafrost, 1962: Natl. Research Council Canada, Assoc. Committee on Snow and Soil Mechanics, Tech. Memo. 76, p. 226-231. 
Collins, F. R., 1958, Test wells, Umiat area, Alaska, with Micropaleontologic study of the Umiat field, northern Alaska, by H. R. Bergquist and sections on Temperature measurement studies by M. C. Brewer and Core analyses, Umiat test well 9, by G. L. Gates: U.S. Geol. Survey Prof. Paper 305-B, p. 71-206.

Lachenbruch, A. H., 1957, Three-dimensional heat conduction in permafrost beneath heated buildings: U.S. Geol. Survey Bull. 1052-B, p. 51-69.

Lachenbruch, A. H., Brewer, M. C., Greene, G. W., and Marshall, B. V., 1962, Temperatures in permafrost in Temperature-its measurement and control in science and industry: New Yorl: Reinhold Publishing Corp., v. 3, pt. 1, p. 791-803.

Reed, J. C., 1958, Exploration of Naval Petroleum Reserve No. 4 and adjacent areas northern Alaska, 1944-1953, Part 1, History of $\mathrm{t} 1 \mathrm{~s}$ exploration: U.S. Geol. Survey Prof. Paper 301, 192 p.

U.S. Geological Survey, 1958, Quartity and quality of surface waters of Alaska, October 1950 to September 1953: U.S. Geol. Survey V'ater-Supply Paper $1466,243 \mathrm{p}$. 